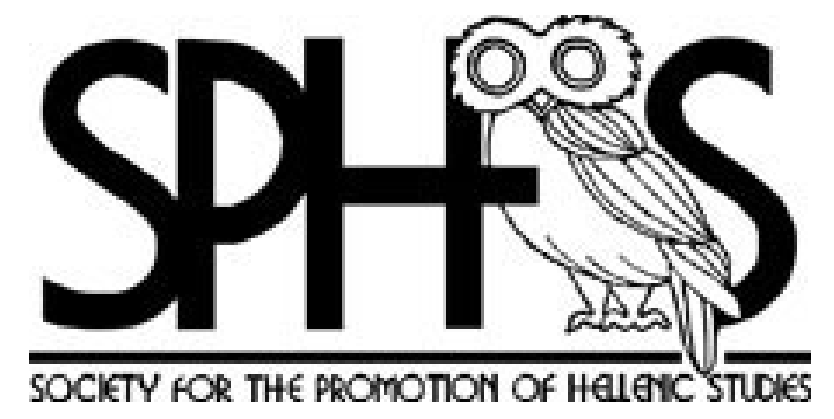

The Master of the Troilos-Hydria in the British Museum Author(s): J. D. Beazley

Source: The Journal of Hellenic Studies, Vol. 32 (1912), pp. 171-173

Published by: The Society for the Promotion of Hellenic Studies

Stable URL: http://www.jstor.org/stable/624139

Accessed: 22/12/2014 18:09

Your use of the JSTOR archive indicates your acceptance of the Terms \& Conditions of Use, available at http://www.jstor.org/page/info/about/policies/terms.jsp

JSTOR is a not-for-profit service that helps scholars, researchers, and students discover, use, and build upon a wide range of content in a trusted digital archive. We use information technology and tools to increase productivity and facilitate new forms of scholarship. For more information about JSTOR, please contact support@jstor.org.

The Society for the Promotion of Hellenic Studies is collaborating with JSTOR to digitize, preserve and extend access to The Journal of Hellenic Studies. 


\section{THE MASTER OF THE TROILOS-HYDRIA IN THE BRITISH MUSEUM.}

\section{[Plates II., III.]}

AT the sale of the Forman collection, a hydria with figures of Troilos and Polyxena was purchased for the British Museum. Cecil Smith, in the sale catalogue, described it as in the style of 'Euthymides ?' ; but I cannot agree with him.' Eight other vases by the same hand are known to me; and I beg leave to call this anonymous painter 'the master of the Troiloshydria in the British Museum.' He is no genius ; but one of his vases, the krater in Copenhagen, is a respectable performance; and others are not without animation.

\section{Hydriai.}

Rim simple, no detached lip: pattern 9. Foot double curve. Picture on body. Band of pattern helow the picture.

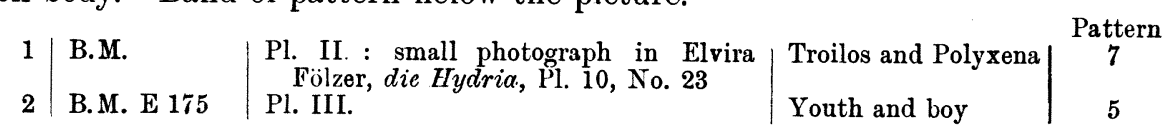

\section{Amphorae (shape Furtwängler, Cat. No. 35).}

Foot of 3, usual early foot with two degrees; rays at base. Foot of 4, restored (so is a great part of the vase). Handles ivied. Pictures framed. 4 has a r.-f. palmette at the handle.

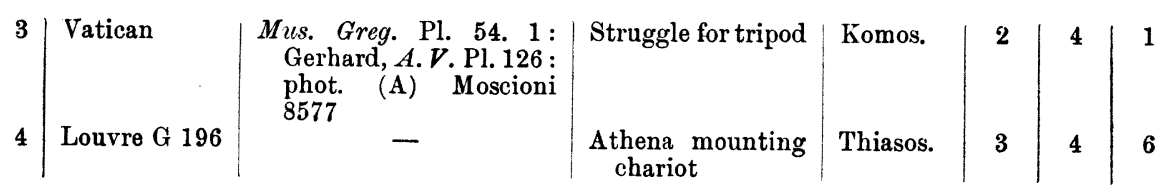

\section{Stamnoi.}

Mouth and foot of 8 restored. 5, 6, and 7 same rim, neck, and foot: simple rim like the hydriai, with pattern 9 ; very short neck; foot thin black

1 P. 67, No. 339. To the list of Euthymides' works given in J.H.S. xxx. p. 41, I would add the psykter with Herakles and
Dionysos formerly in the Magnoncourt collection (Gerhard, $A . V$. Pll. 59-60). It is now in the 
disc. Handles : 5, 6, 8, straight, flat inside ; 7, rounded and recurved. 8 has rays at base. Usual tongues above picture: band of pattern below pictures on 5,6 , and 7 ; on 8 , all round the vase. The drawing is very bad indeed, except on 5 .

5 Florence 3986

6 Louvre G 182

7 Louvre G 184

8 Mannheim 60

$$
\begin{aligned}
& \text { Boxers } \\
& \text { Gods } \\
& \text { Gods }
\end{aligned}
$$

Women at bath

Victor

Warrior attended

Boys and youths

\begin{tabular}{l|ll}
$\mathbf{5}$ & & 5 \\
$\mathbf{5}$ & & \\
$\mathbf{5}$ & & 5 \\
& $\mathbf{5}$ &
\end{tabular}

\section{Calyx-krater.}

Above, pattern 8 : below, black. At base, rays. At handles, palmette motives: tongues at base of handles.

$9 \mid$ Copenhagen $126 \mid$

(B) Ann. 1846, Pl. M : Lange, Darstellung, p. 100

Athena mounting chariot $\mid$ Athletes

Relief-lines are always used for the contour of the face. The profile is very characteristic, flat pointed nose, large chin, and thick projecting lips. The nostril is sometimes marked, sometimes not: twice on 2 and 9 , once on $3,4,6$, and 8 . The eye is large and wider than usual from upper to lower lid, The pupil is often dot-and-circle. The ear has the form ?. The head is narrow from back to front. The mouth is usually open.

On 9 , the collar-bones are rendered thus: $>$ f down of the curved parts seen on 2 recurs on 3 .

When the breast is frontal, the lower breast-lines join at a right angle, $\perp$.

The breast in profile has this shape, $\mathcal{Y}(2,8)$.

The nipples are large black circles $(6,9)$, or black semi-circles cut off by the lower breast-line $(2,3$; brown on 9$)$; once a large brown $\operatorname{dot}(4)$.

The brown transverse line across the breast above the nipples, to be seen on 2 , also occurs on 3 and 9 .

The navel is composed of two black lines, $=$, the upper sometimes straight, sometimes convex or concave to the lower. The navel-pubes line is black.

Brown interior lines represent the profile knee-cap, but the upper end of the tibia is not rendered.

The frontal knee is as follows: 9 (3 and 9).

The ankle, where indicated, is $\mathbf{U}$, or, the lines touching, $\mathbf{U}$

The frontal foot broadens rapidly towards the sole.

The profile feet are rough: $\sum_{m}$ : on 1 and 2, the separate toes are more carefully drawn.

The right hand of Polyxena on 1 is repeated on 5 ; the right hand of the youth on 2 , on 9 . The thumb is usually rigid.

Like Kleophrades, the Troilos-master particularly affects the simple key-pattern. It is also to be noticed that pattern No. 7 is Kleophradean ${ }^{2}$ :

2 J.H.S. xxx. pp. 45, 48, and 51, Nos. 11, 12, $13 \mathrm{~b}$. 
and the simplified egg-and-dot pattern is the variety preferred by Kleophrades. The style of the Troilos-master shows no signs of Kleophrades' influence.

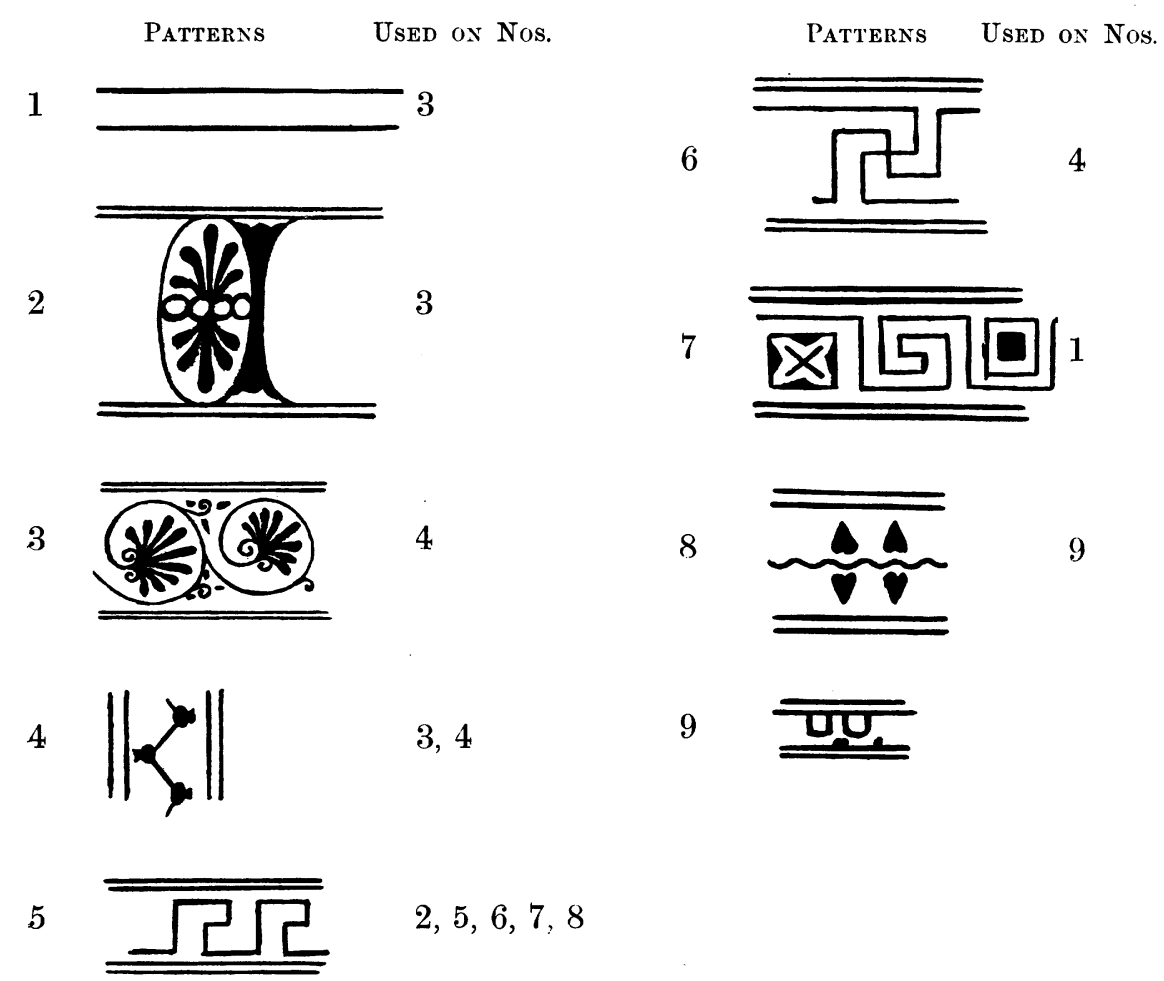

J. D. Beazley. 


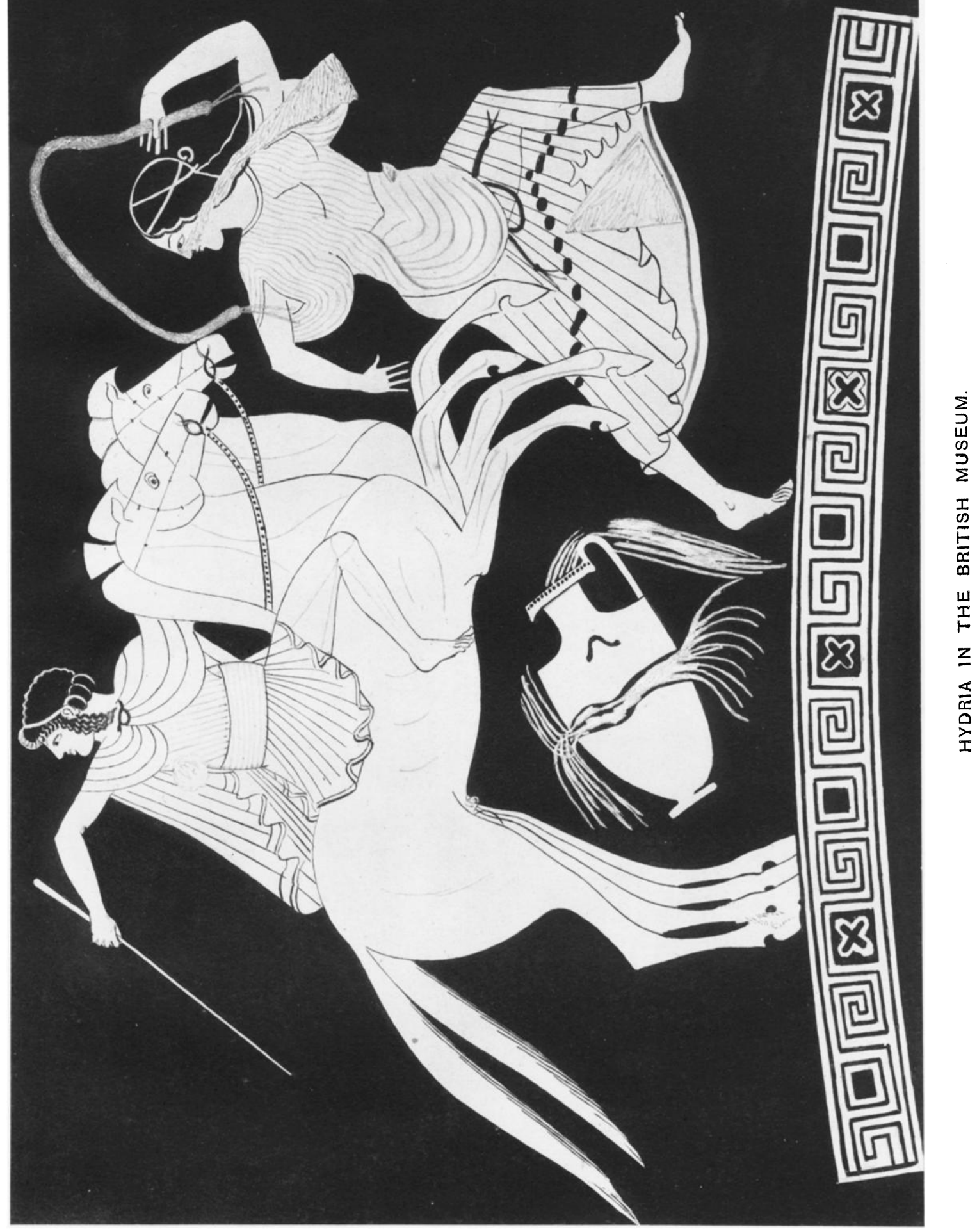




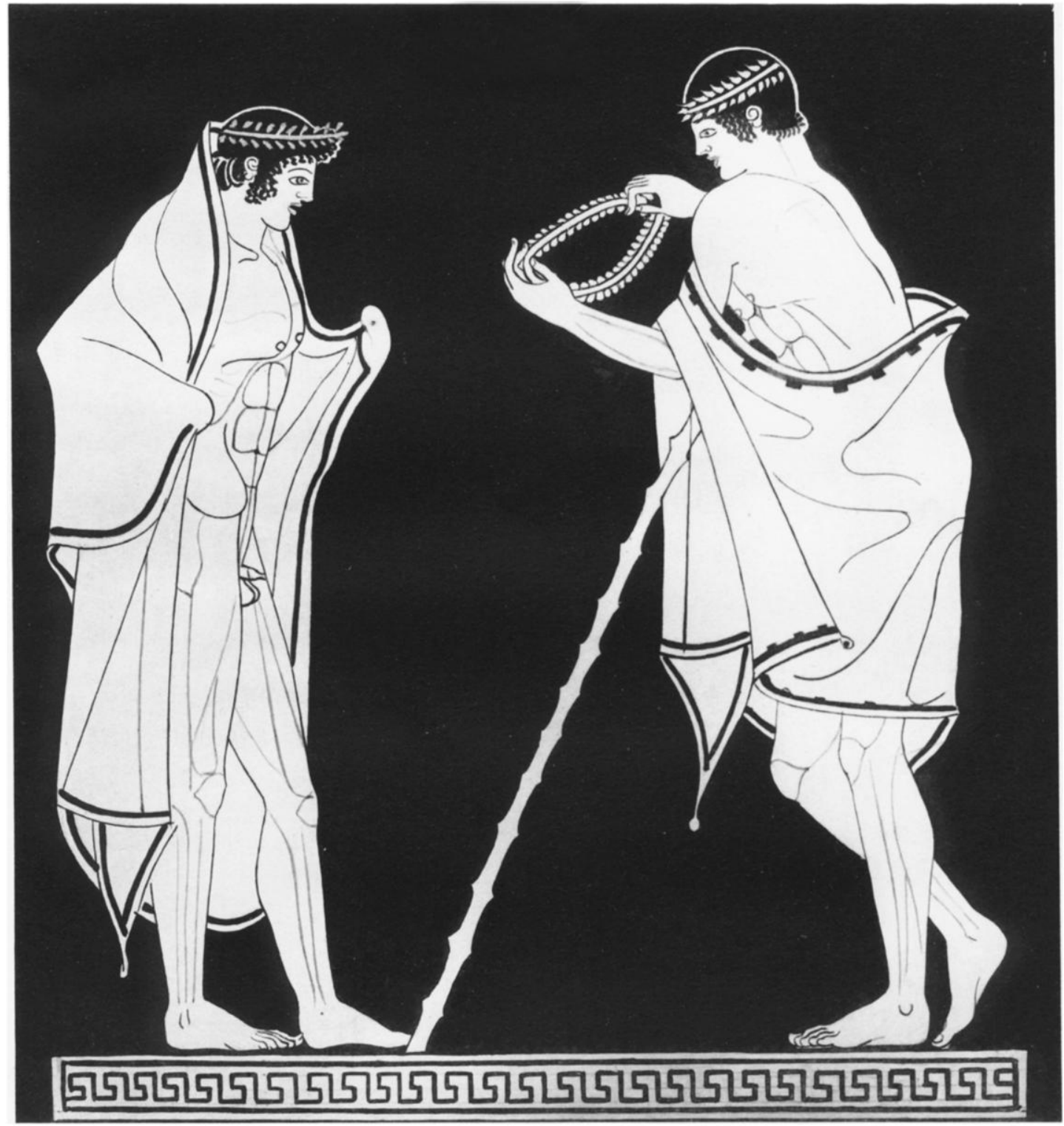

HYDRIA IN THE BRITISH MUSEUM (E 175). 